\title{
Comentários
}

\section{The Crisis of Power and the Futures of Hope}

\author{
Maria Ceci Misoczky ${ }^{(1)}$
}

\section{INTRODUCTION}

To begin, I wish to share with Westwood and Clegg (2003) the hope that it is possible to construct affirmative positions of difference from different positions and perspectives. In that sense, the aim is to avoid the adversarial form supposedly intrinsic to the act of debating and, instead, engage actively and fruitfully in order to produce a better understanding of what is shared and what is contradictory, especially considering our diverse locations in the global scenario.

In this article, power is also considered as a key aspect of the globalization process occurring in recent history. However, the approach is different. One obvious difference may have to do with cultural contextual references. However, the recognition of cultural differences is not enough. Considering that knowledge cannot be detached from power, and that power is attached to geopolitics, my approach is also a consequence of an epistemological and political difference the colonial difference ${ }^{(2)}$.

Mignolo (2003, p. 85) draws a distinction between colonial difference and cultural difference.

The colonial difference is the underlying logic. Power relations holding together cultural differences have been articulated by the coloniality of power ${ }^{(3)}$, from early Christian global designs to the current global coloniality driven by the metaphysics of the market. Intellectual decolonization [...] could help to undo the colonial difference and imagine possible futures beyond the alternative offered by global coloniality and the current reproduction [...] of the colonial difference.

In Latin America, the philosophy of liberation has been the philosophical version of what has been identified as decolonization, opening the gates to the rearticulation of the rationale between knowledge and geo-historical location 
and making clear that the universal claims of European philosophy are linked to the imperial cosmology of the modern colonial world (Dussel, 2002; Mignolo, 2000).

The discourse of modernity emerged in the first instance as an encounter with a radically different culture. It was this encounter, as Dussel explains, that produced a European subject whose very subjectivity was predicated on the conquest, that is, whose subjectivity was defined in terms of their response to the encounter: the conquest. [...] Thus the core of the European subject is not a disciplinary regime of normalizing practices but a conquest of alterity, upon which normalization is organized toward establishing the justice and justifiability of the conquest. To truly subvert the coherence of this system and its characteristics tactics of power one must not simply repudiate the modern disciplinary regime but develop a rearticulated relation to the Other. [...] The new postmodern cynical turn toward political and axiological nihilism has already proven itself quite capable of maintaining a subject that retains the right to conquer and continues to believe in its own global superiority; in fact, its own cynicism is now used to establish that superiority against the more 'primitive' or 'unsophisticated' cultures that retain the capacity for belief in values, religion, and the possibility of political optimism (Alcoff, 2000, p. 255).

Instead, the concept of transmodernity, developed by Dussel (2002), allows the understanding of modernity as being not a strictly European but a planetary phenomenon, to which the colonies and their people have contributed, although our contribution has not been acknowledged. The notion of transmodernity signals the possibility of a critical dialogue with alterity, breaking with the idea of an abstract universalism. It is a space for pluri-versality, for different projects as part of a universal project.

To accomplish this project, some previous conditions need to be fulfilled. Santos (2003) approach - named sociology of absences - can be very helpful to that end. It consists of an inquiry that aims to explain that what does not exist is in fact actively produced as nonexistent. Non-existence is produced whenever a certain entity is disqualified and rendered invisible, unintelligible, or irreversibly discardable. Santos (2003, p. 5) describes five logics or modes of production of nonexistence:

1) the monoculture of knowledge and rigor of knowledge - it consists of turning modern science and high culture into the sole criteria for truth and aesthetic quality, respectively;

2) the monoculture of linear time - meaning and direction have been formulated in different ways over the last two hundred years (progress, revolution, 
modernization, development, globalization) - it produces nonexistence by describing as backward whatever is asymmetrical vis-à-vis whatever is declared forward;

3) social classification - it consists of distributing populations according to a monoculture that naturalizes hierarchies - nonexistence is then produced as a form of inferiority;

4) the logic of the dominant scale - for the monoculture of the universal and of the global, the scale adopted as primordial determines the irrelevance of all other possible scales, nonexistence is produced under the form of the particular and the local;

5) the logic of productivity - it resides in the monoculture of the criteria of capitalist productivity and efficiency, applied to nature, non-productiveness is sterility, applied to labor it produces discardable populations, laziness, professional disqualification and lack of skills.

The production of these absences results in the waste of the social experience of the five nonexistent: the ignorant, the residual, the inferior, the local and the non productive. As a reaction, the sociology of absences proclaims an ample version of realism that includes the realities rendered absent by silence, suppression, and marginalization - realities that are actively produced as nonexistent. This sociology demands both an epistemological and a democratic imagination.

Until now, what I have written has been an introduction to clarify my position. I am writing from the perspective of the colonial difference. I am also producing this text as part of a collective project that aims to render visible organizational worlds condemned to nonexistence by the hegemonic definition of organization around which OS, as a field of knowledge, is built (Misoczky \& Böhm, 2006). Finally, I truly believe in the promises of the project of transmodernity, in which all efforts in the direction of a global dialogue must be undertaken.

The argument of this paper evolves around the idea that in our field of academic practice we lack theories and methods in order to understand the complexity of power relations in the current social and political context. We could only perceive globalization in its ambiguity if we looked at it not only from the top down (or from the centers of power to the periphery of the world system), but also from the bottom up. Then we could refer to aspects such as the contradictory potential of globalization expressed by processes of re-localization and re-nationalization (Hall, 1991; Lughod, 1991), and we would also be able to perceive the existence of a counter hegemonic globalization. 
However, it is much easier for us, as OS academics, to recognize globalization in its mythic ${ }^{(4)}$ neutrality: as a generic process defined in terms of the electronic revolution, the creation of transnational social spaces, and the expansion of the cultural ideology of consumerism; as a reference to a global-human condition, to a consciousness of the globe as such, to the crystallization of the entire world as a single space (Robertson, 1987).

Considering our role as globalizing professionals, using the term coined by Sklair (2001) to identify the technical fraction of the transnational capitalist class ${ }^{(5)}$, it becomes evident why we tend to reproduce or help to produce the current relations of power ${ }^{(6)}$. In that role, we also contribute towards diffusing a great deal of fatalism. Even progressive academics in our field tend to accept that there is no alternative to neoliberal globalization, to the rule of total market, to consumerism as the supreme act through which we recognize ourselves as members of a community. Power, therefore, is perceived as being highly concentrated in few spheres of social life.

Even recognizing the crisis of the current process of globalization in at least two obvious aspects - the threat to human life and the imminent destruction of the planet - we are still blind to the various forms of resistance being practiced around us. As we are not prepared to recognize these practices as resistances and struggles driven by the need to construct alternatives within contexts of radical forms of democracy, we contribute to the fatalist view of the future, recognizing as resistances only actions and organizations that are, in fact, the darkest side of the hegemonic process, driven by the same logic and using the same means guided towards the same end of pure destruction.

As OS academics, we do not have a theoretical and methodological arsenal that allows us to explore the open field of organizational practices of resistance. One basic constraint that has to be overcome concerns the predominance of a restrictive and insufficient definition of organization. The dominant definition of organization still prevailing in our disciplinary field is obviously connected to business practices, being oriented by concepts such as structure and division of labor, leadership, membership, success and failure, rules and performance. Let us examine the definition of McCarthy and Zald (1987, p. 20), proponents of the field of studies known as social movement organization - SMO: a social movement organization is a "complex, or formal, organization which identifies its goals with the preferences of a social movement or countermovement and attempts to implement these goals". It is clear that this definition only applies to very formal and structured organizations. It also disconnects organization from movement ${ }^{(7)}$. As we lack lenses to recognize fluid, flexible, networked, unstable, horizontal 
practices of organization as organization, we actively contribute towards declaring as nonexistent organizational practices which are not immediately recognizable by the monoculture of the OS scientific field.

We are living under an unprecedented concentration of power and, paradoxically, an intense dispersion of power - and this is one of the key aspects that define the actual crisis of power. If we understand globalization as a process and a totality, it is possible to perceive how it is incessantly reproduced and undone in the context of disputes and aspirations from different social actors; despite the existence of an enfolding dimension that includes and permeates communities, ethnos and nations. The totality penetrates the parts in their core, redefining their specificities. However, in order to exist, this total social phenomenon has to localize itself, has to spread its roots in the daily practices of human beings. Without achieving this, it would be merely an abstract expression of social relations (Ortiz, 2003). In this process resides the paradox of its simultaneous strength and weakness.

\section{Global Capitalism and the Utopia of Total Market}

The most disseminated view of globalization is based on the myth of its inevitability, represented by an unprecedented concentration of power driven by impersonal forces and affecting all lives everywhere. This myth can only generate impotency and paralysis.

In the same way as capitalism, this version of globalization is governed by an abstraction, relying on the fetishism of the market and its institutions in the global scale. It projects an abstract transcendentalism, promising the complete realization and unity of humankind around sacred market institutions. It promises endless growth, the satisfaction of all possible desires and the acceptance of the destruction of human beings and nature, trusting in salvation by the market. The total market becomes the perfect present; a gear of self-reproduction and constant self-expansion. This utopia ${ }^{(8)}$ is not perceived as such, since its utopian character resides precisely in the promise that its total fulfillment or application cancels out all utopias. The basic thesis is: whoever destroys utopia fulfills it (Hinkelammert, 1993).

A key actor in the construction of the utopia of total market is represented by transnational corporations. Widening the perspective, Sklair (2001) proposes the concept of transnational practices to identify practices that originate with nonstate actors and cross state borders. They are analytically distinguished in three spheres: economic, political and cultural-ideological. The transnational corporation 
is the most important institution for economic practices; the transnational capitalist class for political practices, and the culture-ideology of consumerism for cultural ideological practices.

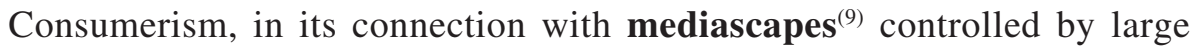
corporations, is a central issue for the understanding of globalization from the topdown approach. Despite the growing amount of research on the construction of identity through consumerism, it is important to bear in mind the existence of immense inequalities within countries and regions. According to Keegan (1984), for marketing purposes there are markets within markets. The adequate strategy should consider that the space of consumerism is not homogenous, with concentration of wealth in some areas and social groups (core areas that should be targeted). However, as the dissemination of consumerism is performed through various elements of communication employed by the media, it creates symbolic representations that also reach those excluded from the core areas. Hence, poorer sections of society make a great effort to obtain goods and a lifestyle well beyond their reach. The perverse effect is both the adverse impact on their quality of life and the identity crisis, which result in many forms of urban violence and sectarian practices

Another symbolic construction related to the myth of globalization concerns the weakness or even disappearance of the role of the nation state. However, if we understand power as a social construction which, as Gramsci (1971) wrote, at some point of the process becomes crystallized into complex superstructures of the capitalist society; it is not possible to discard it.

Wood (2003, p. 134) reminds us that capitalism is, by nature, imperfect. In fact, the laws of the market constantly threaten to disrupt the social order.

Yet capitalism needs stability and predictability in its social arrangements probably more than any other social form. The nation state has from the beginning provided that stability and that predictability by supplying an elaborate legal and institutional framework, backed by its coercive force, to sustain the property relations of capitalism, its complex contractual apparatus and its intricate financial transactions. [...] The state still provides the indispensable conditions of accumulation for global capital, no less than for very local enterprises; and it is, in the final analysis, the state that has created the conditions enabling global capital to survive and to navigate the world. It would not be much to say that the state is the only non-economic institution truly indispensable to capital. (Wood, 2003, p. 134) 
Even the apparent failure of global integration is, in fact, functional. The fragmentation of the world into separate economies marked by uneven development is as essential to globalization as is the free movement of capital. In fact, subordinate economies must be made vulnerable to the dictates of the capitalist market by means of certain methods, such as the structural adjustment policies in the last decades.

Admitting the remaining relevance of the nation state ${ }^{(10)}$ opens the way for understanding the crisis of power in its connection to this system of multiple states, in that it creates great potential for disorder, resistance and opposition. "Those states are subject to their own internal pressures and oppositional forces" and not even the most advanced military force "can keep this global system in line all at once, by means of constant direct coercion" (Wood, 2003, p. 139).

At this point I want to make a historical register, allowing the understanding of the current phenomenon of state terrorism from the perspective of the colonial difference.

11 September, 1973 is more than a symbolic date for the political context of Latin America. It is a reference that allows us to understand the connections between the new totalitarianism and that of the past. The defeat of Salvador Allende's constitutional government in Chile was a terrorist act with the active support of the USA. It was also the landmark for a long period of National Security Dictatorships in the South of Latin America. These totalitarian regimes destroyed, through tactics of murdering, kidnapping and torturing, projects of national and social liberation that were being nurtured in our countries, and also launched the first successful neoliberal policies. 11 September, 2001 provided the excuse for the war on terror, which was required to support the current strategy of globalization. From Augusto Pinochet to Paul Bremer ${ }^{(11)}$, from Chile to Iraq, the same subjacent logic: a mandate, established by violence and the violation of human rights, for the construction of the perfect neoliberal regime. Therefore, we are back to the concept of the National Security Dictatorship, with the difference being that we now have a worldwide dictatorship that is rhetorically justified as being the protector of democracy and human rights ${ }^{(12)}$ (Hinkelammert, 2003).

This is the hegemonic strategy of globalization: on the one hand, the peaceful expansion of the free-market economy by means of the symbolic construction of myths - the utopia of total market, the inexpugnable power of transnational corporations, consumerism as the only possible way of achieving a meaningful 
identity, the obsolescence of the nation state; on the other the omnipresence of violence - the infinite war as a constant threat without constraints either of time or geography.

I am not saying, by any means, in the style of Laclau and Mouffe (1985), that we are facing a purely discursive phenomenon. Instead, I have made it very clear that the process at stake is the result of an intense articulation of discursive and non-discursive practices, retaining the distinction made by Foucault (1981) and dismissed by Laclau and Mouffe (1985). Following Dussel (2001), I defend that the only way for critical engagement with the phenomenon of neoliberalism, late capitalism and globalization, is to develop a logic of contingency that finds out the importance of the political struggle for hegemony, and at the same time defines the material reference to its exercise: to preserve and improve the reproduction of life for all the members of the social body

\section{Global Resistances and the Futures of Hope}

"All hope abandon, you who enter in!" Dante Alighieri (Inferno: Canto III)

One important condition for the stability of hegemonic globalization is the dissemination of hopelessness. Here resides the strategic importance of disseminating myths. The myth purifies things, abolishing the complexity of human acts, "it gives them the simplicity of essences, it does away with all dialectics, with any going back beyond what is immediately visible, it organizes a world which is without contradictions" (Barthes, 1973, p. 156). If myth is depoliticized speech, part of the counter hegemonic strategy must be the construction of a politicized speech.

Part of this politicization involves the recognition of a constellation of spaces and organizations where civil citizenship is articulating and resisting hegemonic globalization. These organizational worlds are around us, and a crucial task for politicizing OS discourse is precisely to render these worlds visible. However, to perceive and understand this complex phenomenon we need to develop forms of knowledge and practices of research that avoid the trap of the sociology of absences. In order to identify and enlarge the signs of alternative and possible future experiences, under the guise of tendencies and latencies, which are actively ignored by hegemonic rationality and knowledge, Santos (2003) proposes the sociology of emergences. 
Based on Ernst Bloch (1995) and on his concept of 'not yet' as a category that expresses what exists as mere tendency, as the way in which the future is inscribed in the present, Santos (2003, p. 9) develops the proposal of an inquiry into the alternatives that are contained in the horizon of concrete possibilities. "It consists of undertaking a symbolic enlargement of knowledge, practices and agents, in order to identify therein the tendencies of the future (the Not Yet) upon which it is possible to intervene so as to maximize the probability of hope vis-à-vis the probability of frustration."

When we look at the globalization process from a bottom-up perspective, bearing in mind the dialectics between the sociology of absences and the sociology of emergences, we can then recognize the existence of a vast set of networks, initiatives, organizations and movements, struggling against the social, political and economic consequences of hegemonic globalization. A good deal of counter hegemonic struggle occurs in direct opposition to the aspects considered above: fetishism of the market, predatory practices of transnational corporations, consumerism and war. At the same time, national and local spaces and scales of action are intensely valued, connecting two distinct processes: global collective action and national or local struggles.

Just now, as I am writing, I have received an e-mail alert. It is a message carrying a World Social Forum (WSF) Bulletin. For those not familiar with this open space, the $\mathrm{WSF}^{(13)} 7^{\text {th }}$ edition is scheduled to be held in Nairobi, Kenya, from the 20th to the 25th of January 2007. During this edition the fourth day of the event will be dedicated to the planning of common actions to be implemented during the rest of the year. Let us take the chance offered by the global system of communication - evidence that mediascapes are also an instrument for counter hegemonic efforts - and explore the objectives of action that resulted from a previous consultation carried out, over the internet, in 2006 and consolidated by the Methodology and Content Commissions in September of the same year ${ }^{(14)}$.

1) Building a world of peace, justice, ethics and respect for diverse spiritualities.

2) Liberating the world from the domination of multinational and financial capital.

3) Ensuring universal and sustainable access to the common goods of humanity.

4) Democratizing knowledge and information.

5) Ensuring dignity, defending diversity, guaranteeing gender equality and eliminating all forms of discrimination. 
6) Guaranteeing economic, social and cultural rights, especially the rights to food, healthcare, education, housing, employment and decent work.

7) Building a world order based on sovereignty, self-determination and rights of the peoples.

8) Constructing a people-centered and sustainable economy.

9) Building real democratic political structures and institutions with people's participation in decisions and control of public affairs and resources.

This fragment is taken here as an illustration of a global collective effort for counter hegemonic politics, aspiring to build a consensual project that reaches beyond the fragments of resistant subcultures and movements, transcending narrower interests of disperse multiple identities, drawing together social forces around an alternative ethical and political conception of the world.

The WSF, first convened in 2001, has become an undeniable space for the necessary meeting, exchange and articulation of subaltern groups. Contradicting the sociology of absences, which insists in presenting the Forum as a kind of inoffensive leftwing carnivalesque festival, it has been, since the first gathering, a very effective space for the creation and expansion of networks and partnerships, providing a vital opportunity for the needed work of translation between local and global struggles. In a short period of time, it has reached and taken root in many places of the globe. "By enlarging the available and possible social experience, the WSF created a global consciousness for the different movements and NGOs, regardless the scope of their action. Such a global consciousness was crucial for creating a certain symmetry of scale between hegemonic globalization and the movements and NGOs that fought against it" (Santos, 2003, p. 12).

Since its first meeting, there has been a constant concern regarding organizational issues. Let us consider the message from Onyango Ollo, National Coordinator of the Kenya Social Forum ${ }^{(15)}$, as an illustration of the ongoing process of articulation as well as the expression of concerns about the effectiveness of the process.

On a global scale, the World Assembly of Social Movements has held a series of meetings and exchanges on how best to use the WSF space to galvanize social movements. At the continental level, the South African based Khanya College and the newly founded Sankara Centre for Social Movements in Kenya are determined to see that the WSF 2007 event is an occasion to network and map out joint actions with other social movements from around the world. In 
the same vein, an initiative coming out of Asia and Africa will be a prominent feature of the WSF Nairobi encounter, as activists from the two vast continents map out the elements of Africa-Asia Solidarity. A similar process is underway involving Latin America and Africa. At the formal organizing level [...] the fourth day of the WSF event [will be used] to solidifying joint actions and campaigns, partly to stave off lingering criticisms and perceptions that over the years the WSF has become little more than a talk shop. [...] Social movements, including dozens in Kenya, want to see the WSF being transformed into a space for organizing and mobilizing against the nefarious forces of international finance capital, neo-liberalism and all its local neo-colonial collaborators.

In the context of Latin America, one consequence of hegemonic globalization has been the precipitation of an unprecedented social holocaust: increased social exclusion, poverty and the vulnerability of very large sections of our societies (Ziccardi, 2002). At the same time, it has been a widespread eruption of popular insurgences and organizations of struggle and resistance ${ }^{(16)}$ (Misoczky, 2006b).

Reflecting on the ongoing contradictions between elites and people in Latin America, Dávalos (2002, p. 355) refers to the emblematic synchronicity of events, in the first months of 1994, when at the same time Mexico was entering NAFTA and the Zapatista guerrilla was being launched. On one side, the desires of modernity and integration to the global market expressed by our elites; on the other the people for whom history has always been a long process of resistance. This moment was also relevant because it contributed towards transforming the local ethnic actor into a social and political actor that was recognized world wide. It was at that moment, which coincides with the Washington Consensus, the defeat of the real existent socialism, and the emergence of the 'third way', that social movements in Latin America became strongly present.

The predominance of nationally-based strategies - even if they are internationalist in orientation - has also been a peculiar characteristic of the political process in our region. According to the assumptions of Hardt and Negri (2004) it is mere and pure anachronism ${ }^{(17)}$, since the nation state sovereignty is disappearing and instead a supra national level is forming a new sovereignty: the global Empire. Despite its popularity, mainly in the Global North, this position is highly contested. Boron (2004) and Wood (2003), for example, as mentioned above, consider the nation state to be even more important in the current phase of global capitalism. For these authors, any counter hegemonic movement can neither ignor nor underestimate that essential role. Instead, for both, the nation state is a strategic target. "Precisely because the imperialism of globalization depends on extending purely economic hegemony and market imperatives far beyond the reach of any 
single state, it is especially dependent on a plurality of subordinate states to enforce those imperatives and to create the climate of legal and political order" (Wood, 2003, p. 138).

The importance acknowledged by Latin-American social movements to the nation state becomes obvious when we consider the recent period, marked, just to mention a few situations, by many popular insurgences in which governments were overthrown - such as the well-known cases of Argentina, Ecuador and Bolivia; many movements that succeeded in achieving the republicization of privatized services - such as the case of water in Bolivia, Uruguay and Argentina; many struggles of resistance against the Free Trade Agreement, defeating the goal of the USA to have it signed with all countries in the region by January, 2006.

For analysts not familiar with our context, it is relatively easy to understand processes like those of Chile, Brazil or Uruguay, where the social forces still channel their aspirations through a conventional system of political parties. However, it is harder to understand processes like that of Venezuela and Bolivia, where there is a context of hyper-political mobilization which has often been confusedly characterized as populism ${ }^{(18)}$. Populism is defined as being a practice directed towards the integration of excluded sectors into a political community already existing. In Venezuela and Bolivia, there is an intense mobilization destined to refound or re-construct the polis. The social subject of this model is the mobilized people, and the main questions answered concern the possible costs of the intense polarization between local elites and the masses, and the difficulties of institutionalization beyond personal leadership (Garretón, 2006).

In these countries, as well as in the whole region, there is also an aspiration and an intense effort directed at the construction of collective identities - mixing the recovery of traditional cultural traces with the production of new politicized aspirations.

From a theoretical perspective, it is important to realize that if we accept the assumption that identity can only be produced individually and within market relations of consumerism, we would still have no explanations for the emergence, trajectories, and impacts of social movements. In search for answers researchers have turned to collective identity to fill the gaps in resource mobilization and political process accounts. Collective identity has been treated as an alternative to structurally given interests in accounting for the claims on behalf of which people mobilize, an alternative to selective incentives in understanding why people participate, an alternative to instrumental rationality in explaining what tactical 
choices activists make, and an alternative to institutional reforms in assessing movements' impacts (Polletta \& Jasper, 2005).

The construction of collective identity in a context of decolonization demands the effort of contradicting any idea of an inferior ethos internalized as a consequence of the coloniality of power, posing the challenge of questioning our past and projecting new and future subjectivities to overcome the coloniality of Being. This expression refers not only to an originary event of violence, but to the unfolding of modern history. "The coloniality of Being refers to the process whereby common sense and tradition are marked by dynamics of power that are preferential in character: they discriminate people and target communities." (19) (Maldonado-Torres, 2006, p. 106). In that sense, the process of constructing a collective identity includes the paradox of both questioning and valuing our traditions and our history.

Radical critique should take dialogical forms. It should also take the form of radical self-questioning and radical dialogue. The project of searching for roots would be, in this regard, subordinated to the project of criticizing the roots that keep the dominant topology of Being and the racist geopolitics of knowledge alive. Radical diversality would involve the effective divorce and critique of the roots that inhabit dialogue and the formulation of a decolonial and non-racist geopolitics of knowledge. [...] There is much in the world to learn from others who have been rendered invisible by modernity (MaldonadoTorres, 2006, p. 127)

Another category, indispensable for those who wish to recognize and understand the existence of a complex process of globalization from below, is precisely that of power. But here too we need to face theoretical and methodological challenges. We should produce a theory of power that recognizes its creation and dissemination from below. Rauber (2006) defines power as a social relation of forces, omnipresent and omniscient in all manifestations of social and individual life. Power from below refers to a process of transformation in which the new is constructed day by day. The expression has no connection with the scale of the problems to be confronted or with the location of social actors. According to this author, resistances and new constructions transform reality from the present, producing political, ideological and cultural hegemony from below. In such a process, political conscience is the key element of organization, as well as for the production of the social and political subject of the transformations.

To become part of this process, as intellectuals, we would need to open up our questions and understandings to incorporate the hermeneutics of suspicion ${ }^{(20)}$ towards everything that seems ordered and solved, uni-dimensional and linear. 
We could also learn by articulating the knowledge that emerges from below and remains, most of the time, contained in the practices. That is why it is important to rescue and conceptualize these practices, adopting the sociology of emergence as a reference for inquiry.

\section{Final Remarks}

"Do not accept the usual as a natural thing. Because in times of disorder, of organized confusion, of dehumanized humanity, nothing must appear to be natural. Nothing must appear to be impossible to change".

Bertold Brecht

Crisis is a word usually linked to ideas such as unstableness, uncertainty, tensions, disruptive interactions, evident conflicts, threats to established values, disorder. The idea of a crisis of power, in this article, expresses this perception: we are living a paradoxical context of intense concentration and absolute diffuseness of power; overlaps and contradictions between competing centers of power and organizational projects; direct physical violent confrontation as well as subtle symbolic disputes. Some evidence of this crisis may be found in the unprecedented systemic risks and insecurities of the present (Beck, 2002); or in the strategic shift from soft power to hard power bringing security into a closer relation with globalization and obviously expressed by the war on terror (Fairclough, 2006).

The crisis of power and the strategy of hard power contribute towards denaturalizing the globalization process. It brings into light the presence of actors, the resources of physical power implicated, the role of corporations and national states; it politicizes discourse. At the same time, counter hegemonic globalization is re-including hope in the political culture and confronting the barrier of symbolic reification, conceiving the future as something to be built in the present through self conscience and organization.

However, the resurgence of hope is not enough for the outcome of better times for the victims of the system. It is necessary to bear in mind the immense capacity for recovery and reconstruction of the capitalist system. Therefore, we should retain the constant presence of both an extreme optimism and an intense reasonable pessimism. 
From an ontological dialectical perspective, "history is produced as the result of conflicts, in which the emergence of new forms of consciousness leads to a shift in power relations which makes this new form of consciousness supreme over the erstwhile dominant form of consciousness" (Cox, 1996, p. 77). As OS academics, we could contribute to this emergence, since we engage in a collective effort to reflect on the novelty of organizational processes and practices silenced by the still dominating sociology of absences. For that, we would have to develop theories and methods of investigation that could become relevant and useful to organizations that are attempting in various ways to bring about change that works for people.

Such a project depends on sharing an ethical and political view regarding the future of humankind, as well as an intense intercultural effort seeking an expansion of our perception of what already exists and of the domain of possible experiences, broadening our capacity for reflection and analysis.

\title{
Notes
}

\begin{abstract}
${ }^{1}$ Post-graduation Program of Administration, Federal University of Rio Grande do Sul.
${ }^{2}$ The colonial difference is the difference created by modern Western thought with respect to other categories of thought that had been reduced to nonexistence.

${ }^{3}$ Coloniality of power is a key notion, developed mainly by Quijano, A. (2000). Coloniality of power, ethnocentrism, and Latin America. Neplanta, 1(3), 533-580. It defines a global hegemonic model of power, in place since the conquest of America, that articulates race and labor, space and peoples, according to the needs and to the benefits of the center of the world system. Coloniality is constitutive of modernity, not just a derivative of modernity. As a consequence we are still living under the same regime. In the Brazilian OS context, the notions of coloniality of power and of knowledge were applied by Misoczky, M. C. (2006a). Sobre o centro, a crítica e a busca da liberdade na práxis acadêmica. Cadernos EBAPE-BR, 4(3), 1-13. For the Latin American OS context see Ibarra-Colado, E. (2006). Organization studies and epistemic coloniality in Latin America: thinking otherness from the margins. Organization, 13(4), 436-488.
\end{abstract}

${ }^{4}$ By myth I am referring, following Barthes (1973), to a mode of signification, a type of speech. From the semiotical perspective, myth has the task of giving to an historical intention a natural justification, and making contingency appear eternal. "Myth is constituted by the loss of the historical quality of things: in it, things lose the memory that they once were made. The world enters language as a dialectic relation between activities, between human actions; it comes out of myth as a harmonious display of essences. A conjuring trick has taken place; it has turned reality inside out, it has emptied it of history and has filled it with nature, it has removed from things their human meaning so as to make them signify a human insignificance. The function of myth is to empty reality: it is, literally, a ceaseless flowing out, a hemorrhage, or perhaps an evaporation, in short a perceptible absence."(Barthes, 1973, p.155) 
${ }^{5}$ The other three fractions of the transnational capitalist class are, according to Sklair (2001), those who own and control major transnational corporations and their local affiliates (corporate fraction); globalizing state or inter-state bureaucrats and politicians (state fraction); and merchants and media (consumerist fraction).

${ }^{6}$ The role of business gurus in the creation of the myth of globalization is self-evident. Running the risk of being too obvious I wish to mention the contribution of just a few of these gurus in making globalization appear as a natural, necessary and uncontrollable force. Ohmae, K. (1990). The borderless world: power and strategy in the interlinked economy. London: Collins. predicted that global forces, global culture or globalizing belief systems and ideologies, are becoming so powerful that the continuing existence of the nation-state is in serious doubt. Of course Porter, M. (1990). The competitive advantage of nations. New York: Macmillan, equated nations to enterprises, and established competition as the supreme value on earth. And, yes, Fukuyama, F. (1995). Trust: the social virtues and the creation of prosperity. London: Hamish Hamilton, a former analyst of Rand Corporation, after the end of the story now declares trust and strong ethic values (sic) as the means for achieving global prosperity.

${ }^{7}$ Some OS authors - such as Cooper, R. (1976). The open field. Human relations, 29(11), 9991017, Cooper, R. \& Burrell, G. (1988). Modernism, postmodernism and organizational analysis. Organization Studies, 10(4), 479-502, Chia, R. (1998). From complex science to complex thinking: organization as simple location. Organization, 5(3), 341-369 and Munro, R. (2003). Disorganization. In R. Westwood \& S. Clegg (Eds.). Debating organization: point-counterpoint in Organization Studies. Oxford: Balckwell Publishing - have attempted to go beyond restricted notions of organization as a form and argue for the conception of organization as a social formation process that is characterized by heterogeneous forces of power and knowledge. However, their positions have not yet prevailed in the field. They have also been subjected to some criticism for considering the organization as pure movement, pure fluidity (Böhm, S. (2005). Repositioning organization theory: impossibilities and strategies. Basingstoke: Palgrave Macmillan).

${ }^{8}$ Hinkelammert, H. (1988). Crítica à razão utópica. São Paulo: Edições Paulinas, considers the projection of utopias as an inevitable dimension of human thought, allowing us to think of impossible desires and to construct, based on it, the space for a possible realization. In the critique of utopia what matters is to illuminate the fallacy of the transcendental illusion of utopian reason, when it projects abstract concepts and conceive them as a reachable reality. When utopian reason works that way, the aspired totality is imagined as presence. As a consequence, everything that disturbs the concretion of perfect idealization is perceived as a disfunction that must be suppressed. This is precisely the case of the utopia of total market.

${ }^{9}$ According to Appadurai, A. (1996). Modernity at large: cultural dimensions of globalization. Minneapolis: University of Minnesota Press, mediascapes refer to the electronic capabilities to produce and disseminate information which are now available to a growing number of private and public interests around the world.

${ }^{10}$ Even Drucker, P. (1997). The global economy and the nation state. Foreign Affairs, 76(5), 158165 , recognized the "amazing resistance" of the nation state. "In all probability, the nation state will survive the globalization of the economy and the information revolution that accompanies it."(p.160).

${ }^{11}$ This connection is also made by Harvey, D. (2005). A brief history of neoliberalism. Oxford: Oxford University Press 
12 "Human rights were transformed into humanitarian aggression: the violation of the rights of those who violate rights. [...] The violator of human rights becomes a monster, a wild beast to be eliminated without the minimal questioning of its human rights. It loses its character as a human being. [ ...] But the inversion of human rights has another consequence. The annihilation of a country only requires that the country violate human rights. It is not necessary to show or discuss other reasons. [...] It is then possible to threaten the country with annihilation in a legitimate manner and, in the case of the refusal to submit, with actually annihilating it.' (Hinkelammert, 2004, p. 2). Hinkelammert, H. (2004). The hidden logic of modernitiy: locke and the inversion of human rights. Worlds and Knowledges Otherwise, 1(1), 2-27.

${ }^{13}$ The World Social Forum is an open meeting place where social movements, networks, NGOs and other civil society organizations opposed to neo-liberalism and a world dominated by capital or by any form of imperialism come together to pursue their thinking, to debate ideas democratically, for formulate proposals, share their xperiences freely and network for effective action. Since the first world encounter in 2001, it has taken the form of a permanent world process seeking and building alternatives to neo-liberal policies. This definition is found in its Charter of Principles, the WSF's guiding document.The World Social Forum is also characterized by plurality and diversity, is nonconfessional, non-governmental and non-party. It proposes to facilitate decentralized coordination and networking among organizations engaged in concrete action towards building another world, at any level from the local to the international, but it does not intend to be a body representing world civil society. http://www.forumsocialmundial.org.br/main.php?id_menu=19\&cd_language=2)

${ }^{14} \mathrm{http}: / /$ wsf2007.org/program

${ }^{15} \mathrm{http}: / /$ www.pambazuka.org/en/category/comment/38952

${ }^{16}$ The last issue of ephemera: theory \& politics in organization is dedicated to Latin America, being composed by analytical and theoretical articles written by Latin America scholars and activists (Available at: http://www.ephemeraweb.org/). Another source of information on the intense mobilization in different countries of the region is the Journal of the Observatorio Social de América Latina - OSAL (Available at: http://osal.clacso.org/espanol/html/revista.html).

${ }^{17}$ Dussel (2002) alerts us that what in the South may be necessary for the social movements, in the North may be considered as a repetition of anachronic theoretical positions, without realising that we are providing answers to new situations, unpredictable, that need to go beyond the deconstructivism practiced in the countries of the North, closed in a certain kind of provincialism.

${ }^{18}$ Usually the qualification of populism is used in a pejorative sense, being a judgment of value, instead of an objective appraisal. It is one of the practices of the sociology of absences, in this case declaring what exists as non existent by labeling it with an inadequate concept.

${ }^{19}$ The current demonization of Muslim subjects has its origins in the process of establishing the colonial differences on the Southern frontier of the Mediterranean (with the Arab world) and on the western frontier of the Atlantic (with the Amerindians). They defined and continue to define the horizon of modernity, and with it, legitimate work, policy and common sense. Today, just like Europe in the 16th Century, the emerging empire is redrawing the boundaries and borders that will define the new order. The obvious dramatic expressions of this process are Iraq and the US-Mexico militarized border. "Discourse around the idea of the defense of the Homeland, which echoes Heidegger's beloved Heimat, furthers racist geopolitics and leads to the justification of military aggressions, which are conceived as missionary work. America has to be defended from evil men who come from evil places. The Middle East and Latin America are first in line, along with those 
other liminal subjects of Western modernities (Africans, blacks, indigenous people and people of color more generally)." (Maldonado-Correa, 2006, p.120)

${ }^{20}$ According to Ricoeur, P. (1970). Freud and philosophy: an essay on interpretation. New Haven: Yale University Press, the hermeneutics of suspicion is a method of interpretation which assumes that the literal or surface-level meaning of a text is an effort to conceal the political interests which are served by the text. The purpose of interpretation is to strip off the concealment, unmasking those interests.

\section{REFERENCES}

Alcoff, L. M. (2000).

Power/Knowledge in the colonial unconscious: a dialogue between Dussel and Foucault. In L. M. Alcoff \& E. Mendieta (Eds.). Enrique Dussel's philosophy of liberation (pp. 249-265). Boston: Rowman \& Littlefield Publishers Inc.

Barthes, R. (1973).

Mythologies. London: Paladin Grafton Books.

Beck, U. (2002).

Risk society: towards a new modernity. London: Sage.

Bloch, E. (1995).

The principle of hope. Cambridge: MIT Press.

Boron, A. (2004).

Notas sobre um extravio teóricopolítico no pensamento crítico contemporâneo. In C. E. Martins, F. Sá, \& M. Bruckmann (Orgs.). Globalização, dimensões $e$ alternativas: hegemonia e contrahegemonia (pp. 83-109). São Paulo: Edições Loyola.
Cox, R. W. (1996).

Approaches to world order. Cambridge: Cambridge University Press.

Dávalos, P. (2002).

Entre movimientos socials y la academia: las prácticas intelectuales en América Latina. In D. Mato (Coord.). Estudios y otras prácticas intelectuales Latinoamericanas en cultura y poder (pp. 355-362). Caracas: Clacso y Ceap.

Dussel, E. (2001).

Hacia una filosofía política crítica. Barcelona: Desclée de Brouwer.

Dussel, E. (2002).

Ética da libertação na idade da globalização e da exclusão. Petrópolis: Vozes.

Fairclough, N. (2006).

Language and globalization. London: Routledge.

Foucault, M. (1981).

The order of discourse. In R. Young (Ed.). Untying the text: a poststructuralist reader. London: Routledge. 
Garretón, M. A. (2006).

Sociedad civil y ciudadania en la problemáica latinoamericana actual. In I. Cheresky (Comp.). Ciudadania, sociedad civil y participación política (pp. 145-159). Buenos Aires: Miño y Dàvila Ediciones.

Gramsci, A. (1971).

Selections from the prison notebooks. London: Lawrence and Wishart.

Hall, S. (1991).

The local and the global: globalization and ethnicity. In A. D. King (Ed.). Culture, globalization and the worldsystem: contemporary conditions for the representation of identity (pp.1940). London: Macmillan.

Hardt, M., \&

Negri, A. (2004).

Multitude: war and democracy in the age of Empire. New York: Penguin Books.

Hinkelammert, H. (1993, Septiembre).

Crítica al sistema económico capitalista desde la ética: mundialización de mercados, neoliberalismo y legitimación del poder en la sociedad capitalista atual. Ponencia apresentada en el Congreso de Teología de Madrid, Madrid, Espanha, 12. Retrieved from http//www.eumed.net/ cursecon/textos/Hink-critica.htm

Hinkelammert, H. (2003).

El socavamiento de los derechos humanos en la globalización actual: la crisis de poder de las burocracias privadas. Retrieved December 30, 2003, from http://www.uca.edu.sv/ facultad/chn/c1170/kinkelammert.htm
Keegan, W. J. (1984).

Multinational marketing management. New Jersey: PrenticeHall Inc.

Laclau, E., \&

Mouffe, C. (1985).

Hegemony and socialist strategy. London: Verso.

Lughod, J. A. (1991).

Going beyond global babble. In A. D. King (Ed.). Culture, globalization and the world-system: contemporary conditions for the representation of identity (pp.131-138). London: Macmillan.

Maldonado-Torres, N. (2006).

La topologia del ser y la geopolítica del saber: modernidad, imperio, colonialidad. In W. Mignolo (Comp.). De-colonialidad del ser y del saber en Bolivia (pp.63-130). Buenos Aires: Del Signo.

McCarthy, J. D., \&

Zald, M. N. (1987).

Resource mobilization and social movements: a partial theory. In M. N. Zald \& J. D. McCarthy (Eds.). Social movements in an organizational society. New Brunswick: Transaction.

Mignolo, W. D. (2000).

Dussel's philosophy of liberation: ethics and the geopolitics of knowledge. In L. M. Alcoff \& E. Mendieta (Eds.). Enrique Dussel's philosophy of liberation (pp. 27-50). Boston: Rowman \& Littlefield Publishers Inc. 
Mignolo, W. D. (2003).

Philosophy and the colonial difference. In E. Mendieta (Ed.). Latin American Philosphy: currents, issues, debates (pp. 80-87). Indianápolis: Indiana University Press.

Misoczky, M. C. (2006b).

Editorial - Voices of dissent and the organization of struggles and resistances: a special issue on Latin America. Ephemera, 6(3), 224-239. Retrieved from http:// www.ephemeraweb.org/journal/6-3/63editorial.pdf

Misoczky, M. C. \&

Böhm, S. (2006).

A práxis da resistência e a hegemonia da organização. X Colóquio Internacional Sobre Poder Local, Salvador, BA, Brasil.

Ortiz, R. (2003).

Mundialização e cultura. São Paulo: Editora Brasiliense.

Polletta, F., \&

Jasper, J. M. (2005).

Collective identity and social movements. Annual Review of Sociology, 27, 282-305.

Rauber, I. (2006).

Sujetos políticos: rumbos estratégicos y tareas actuales de los movimientos sociales y políticos en América Latina. Bogotá: Ediciones Desde Abajo.
Robertson, R. (1987).

Globalization theory and civilizational analysis. Comparative Civilizations Review, (17), 20-30.

Sklair,L. (2001).

The transnational capitalist class. Oxford: Blackwell.

Santos, B. S. de (2003, March).

The world social forum: towards a counter-hegemonic globalization. Paper presented at the International Congress of the Latin American Studies Association, Dallas, USA, 24.

Ziccardi, A. (2002).

Pobreza y políticas sociales en America Latina. Buenos Aires: CLACSO.

Westwood, R., \&

Clegg, S. (2003).

The discourse of organization studies: dissensus, politics and paradigms. In R. Westwood \& S. Clegg (Eds). Debating organization: point-counterpoint in organization studies (pp. 1-42). Oxford: Blackwell Publishing.

Wood, E. M. (2003).

Globalization and the State: where is the power of capital? In A. Saad-Filho (Ed.). Anti-capitalism: a marxist introduction (pp. 127-141). London: Pluto Press. 